\title{
TREN PRODUKSI GAS, PRODUKSI GAS TOTAL DAN DEGRADASI SECARA IN VITRO DENGAN PENAMBAHAN ADITIF DENGAN LEVEL BERBEDA PADA SILASE TEBON JAGUNG (Zea mays $L$.)
}

\author{
Trend of Gas Production, Total Production Gas, And Degradation In-Vitro with \\ Addition of Different Level of Silage Maize Stover (Zea mays L.) \\ Ahmad Hafidz Alfiansyah' ${ }^{1)}$, Hartutik $^{2)}$ \\ 1) Mahasisawa Fakultas Peternakan, Universitas Brawijaya, Malang, Jawa Timur, Indonesia, 65145 \\ ${ }^{2)}$ Dosen Fakultas Peternakan, Universitas Brawijaya, Malang, Jawa Timur, Indonesia, 65145 \\ Email: hartutik@ub.ac.id
}

\begin{abstract}
ABSTRAK
Penelitian ini bertujuan untuk mengetahui efek penambahan aditif dengan level berbeda terhadap tren produksi gas, produksi gas total dan degradasi secara in vitro silase tebon jagung ( Zea Mays L). Penelitian ini dilaksanakan di Laboratorium Fakultas Peternakan Universitas Brawijaya. Materi yang digunakan dalam penelitian ini adalah tebon jagung (Zea mays L) dan bahan aditif yang terdiri dari molases, bekatul, pollard dan tepung gaplek. Metode yang digunakan adalah percobaan laboratorium dengan rancangannya adalah Rancangan Acak Kelompok (RAK) pola tersarang dengan 4 aditif, setiap aditif memiliki 3 level penambahan dan dirunning tiga kali dimana running dianggap sebagai blok. Setiap aditif terdiri dari $\mathrm{L}_{0}$ (molases $0 \%$, bekatul $0 \%$, pollard $0 \%$ dan tepung gaplek $0 \%$ ), $\mathrm{L}_{10}$ (molases 10\%, bekatul 10\%, pollard $10 \%$ dan tepung gaplek $10 \%$ ) dan $\mathrm{L}_{20}$ (molases $20 \%$, bekatul $20 \%$, pollard $20 \%$ dan tepung gaplek 20\%). Data dianalisis menggunakan Analisis Ragam dan apabila terdapat perbedaan yang nyata maka analisis dilanjutkan dengan Analisis Uji Jarak Berganda Duncan. Hasil penelitian Hasil penelitian menunjukkan bahwa perbedaan penambahan aditif tidak memiliki perbedaan yang nyata antar perlakuan $(\mathrm{P}>0,05)$ terhadap produksi gas total sebesar $65,1 \pm 12,87 \mathrm{ml}$, degradasi bahan kering (DBK) sebesar 56,28 \pm 5,8\% dan degradasi abahan organik (DBO) sebesar 57,34 $\pm 6,61 \%$. Produksi gas meningkat pesat saat berada di interval waktu pengamatan ke 16 dan 24 jam. Berdasarkan penelitian ini, dapat disimpulkan bahwa penggunaan silase dengan penambahan $20 \%$ tepung gaplek adalah perlakuan terbaik.
\end{abstract}

Kata Kunci : Silase, produksi gas total, degradasi, in vitro.

How to Cite:

Alfiansyah, A. H., \& Hartutik. (2021). Tren Produksi Gas, Produksi Gas Total dan Degradasi Secara In Vitro Dengan Penambahan Aditif Dengan Level Berbeda Pada Silase Tebon Jagung (Zea Mays L.). Jurnal Nutrisi Ternak Tropis 4 (2) 77-87
*Corresponding author:

Hartutik

Email: hartutik@ub.ac.id

Fakultas Peternakan, Universitas Brawijaya, Malang,

Jawa Timur, Indonesia, 65145 


\section{ABSTRACT}

The purpose of this research was to determine the effect of addition different additives and level in maize stover ( Zea Mays L) silage on in vitro gas production trend, total gas production and degradability. The research was carried out at the Feed and Animal Nutrition Laboratory, Faculty of Animal Science, University of Brawijaya. The material of this research is Zea mays $L$ and additives consist of molasses, rice bran, pollard and cassava flour. The method used laboratory experiment in Nested Randomized Block Design with four additives treatment, each treatmnent consist of three level and three running as block. Each treatment consists $L_{0}$ without additives (0\% molasses, $0 \%$ rice bran, $0 \%$ pollard and $0 \%$ cassava flour), $L_{10}$ (10\% molasses, $10 \%$ rice bran, $10 \%$ pollard and $10 \%$ cassava flour), and $L_{20}(20 \%$ molasses, $20 \%$ rice bran, $20 \%$ pollard and $20 \%$ cassava flour). Data were analyzed by analysis of variance and if there were any significant differences would be continued with Duncan's Multiple Range Test. The result showed that the additive did not give any effect $(P>0.05)$ on total gas production $(65.1 \pm 12.87 \mathrm{ml})$, degradability of dry matter $(56.28 \pm 5.8 \%)$ and degradability of organic matter $(57.34 \pm 6.61 \%)$, but the level of additive gave highly significant effect $(P<0.01)$ on total gas production, and degradability. The highest value was $20 \%$ cassava flour with the value total gas production $135.10 \pm 4.09 \mathrm{ml} / 500 \mathrm{mgDM}$, degradability of dry matter $65.21 \pm 2.97 \%$, and degradability of organic matter $68.11 \pm 2.18 \%$. Gas production increased rapidly during the 16 and 24 hour observation intervals. Based on this research, it can be concluded that the best treatment was maize stover with $20 \%$ addition of cassava flour.

Keywords : Silage, digestibility, total gas production, degradability, in vitro.

\section{PENDAHULUAN}

Pakan merupakan aspek terpenting dalam sektor industri peternakan termasuk peternakan ternak ruminansia. Pakan utama bagi ternak ruminansia adalah hijauan yang mayoritas merupakan rumput dan leguminosa. Rumput merupakan pakan sumber serat sebagai sumber energi pada ternak ruminansia. Selain mengkonsumsi rumput dan leguminosa, ternak ruminansia dapat diberi limbah pertanian seperti jerami dan tebon jagung sebagai pakan alteratif.

Tebon Jagung sudah umum digunakan sebagai pakan ternak ruminansia, yaitu seluruh tanaman jagung muda yang dipanen saat berumur 85 hari yang meliputi batang, daun dan buah yang masih muda. Produksi tebon jagung tidak stabil setiap tahun karena produksi tinggi saat musim penghujan dan rendah pada musim kemarau, memiliki kadar air yang tinggi yakni 80 - $90 \%$ (Bunyamin, Efendi dan Andayani. 2013), sehingga mudah rusak dan tidak tahan disimpan lama. Selain itu, memiliki Water Soluble Carbohydrate (WSC) yang rendah yakni sebesar $12,11 \%$ (Despal, Hidayah dan Lubis. 2017; Sjofjan et al., 2020). Oleh karena itu, perlu pengawetan dalam bentuk silase yaitu pengawetan hijauan segar secara anaerob dalam kondisi asam ( $\mathrm{pH} 4)$ dalam suatu tempat yang disebut silo. Pembuatan silase yang berkualitas baik memerlukan persyaratan kadar air $60-70 \%$, mengandung WSC yang cukup.

Kadar WSC pada tebon jagung yang rendah akan menghambat pertumbuhan bakteri asam laktat yang dapat menghambat proses ensilase, sehingga perlu penambahan bahan aditif yaitu molases, bekatul, polard, dan tepung gaplek karena bahan bahan tersebut mudah didapat, murah, dan dapat meningkatkan WSC bahan silase tebon jagung. Penambahan aditif dalam pembuatan silase akan dapat mempercepat penurunan $\mathrm{pH}$ melalui terbentuknya asam laktat oleh bakteri asam laktat (Sjofjan and Adli, 2021). Level penambahan bahan aditif dapat memperngaruhi kualitas silase, silase 
yang baik ditandai dengan adanya aroma asam dan bukan beraroma busuk, memiliki pH rendah (sekitar 4), dan berwarna sedikit kecoklatan (Bunyamin, dkk. 2013), disamping itu silase yang baik tidak berlendir dan tidak berjamur. Rukmana (2005) menyatakan bahwa prinsip pembuatan silase adalah mengubah gula dalam bahan silase menjadi asam laktat melalu proses fermentasi oleh bakteri asam laktat. Kondisi asam akan menurunkan $\mathrm{pH}$ silase karena nilai $\mathrm{pH}$ yang rendah dapat menghambat pertumbuhan bakteri patogen atau pembusuk sehingga silase menjadi awet.Kualitas silase dapat diketahui melalui nilai produksi gas, degradasi bahan kering dan degradasi bahan organik secara in vitro, analisis secara in vitro dilakukan dengan meniru kondisi alat pencernaan ternak ruminansia yang dilakukan di laboratorium. Metode in vitro memiliki kelebihan kelebihan dapat menganalisis sampel dalam jumlah banyak sekaligus, memerlukan jumlah sampel yang sedikit, biaya yang lebih murah dengan waktu yang lebih cepat dibandingkan dengan secara in vivo.

Tujuan dari penelitian ini adalah untuk mengevaluasi pengaruh penambahan bahan aditif dengan level berbeda pada silase tebon jagung yang diinkubasi 21 hari terhadap nilai produksi gas, degradasi bahan kering dan degradasi bahan organik secara in vitro secara in vitro.

\section{Materi Dan Metode Penelitian Lokasi Penelitian}

Pembuatan silase dan pengukuran produksi gas total dan degradasi dilaksanakan di laboratorium Fakultas Peternakan Universitas Brawijaya. Pengambilan cairan rumen dilakukan di Rumah Potong Hewan (RPH) Malang.

\section{Materi Penelitian}

Materi penelitian ini adalah tebon jagung (Zea mays L.) dengan umur potong 85 hari, bahan aditif terdiri dari molases, bekatul, pollard, dan tepung gaplek, cairan rumen dari sapi yang baru dipotong di RPH Gadang Kota Malang serta seperangkat alat dan bahan kimia untuk pengukuran produksi gas dan degradasi secara in vitro.

Rancangan percobaan yang digunakan adalah Rancangan Acak Kelompok (RAK) pola tersarang dengan 4 (empat) perlakuan penambahan bahan aditif yakni : molases, bekatul, pollard dan tepung gaplek dengan level masing-masing aditif $0 \%, 10 \%, 20 \%$. Masing masing perlakuan dilakukan sebanyak 3 (tiga) kali running sebagai kelompok. Adapun perlakuan yang diuji adalah sebagai berikut :
ML0 = Silase Tebun Jagung dengan penambahan Molases 0\%
ML10 = Silase Tebun Jagung dengan penambahan Molases $10 \%$
ML20 = Silase Tebun Jagung dengan penambahan Molases 20\%
BL0 = Silase Tebun Jagung dengan penambahan Bekatul 0\%
BL10 = Silase Tebun Jagung dengan penambahan Bekatul 10\%
BL20 = Silase Tebun Jagung dengan penambahan Bekatul 20\%
PL0 = Silase Tebun Jagung dengan penambahan Polard 0\%
PL10 = Silase Tebun Jagung dengan penambahan Polard $10 \%$
PL20 = Silase Tebun Jagung dengan penambahan Polard $20 \%$
GL0 = Silase Tebun Jagung dengan penambahan Tepung Gaplek 0\%
GL10 = Silase Tebun Jagung dengan penambahan Tepung Gaplek 10\%
GL20 = Silase Tebun Jagung dengan penambahan Tepung Gaplek 20\%

a) Pengukuran produksi gas in vitro dilakukan dengan metode Makkar (1995) menggunakan syringe yang diinkubasi selama 0, 2, 4, 8, 16, 24, 36, 48, 72, 96 jam.

b) Pengkuran degradasi bahan kering dan bahan organik menggunakan residu hasil produksi gas yang diinkubasi selama 96 jam. 


\section{Variabel penelitian}

Tren produksi gas pada jam pengamatan $0,2,4,8,16,24,36,48,72,96$ jam, produksi gas total yang diinkubasi selama 96 jam, degradasi bahan kering (DBK) dan degradasi bahan organik (DBO).

\section{Analisis data}

Analisis data menggunakan analisis ragam dalam Rancangan Acak Kelompok Pola Tersarang. Uji perbedaan antar perlakuan menggunakan Uji Jarak Berganda Duncan.

\section{HASIL DAN PEMBAHASAN}

\section{Tren Produksi Gas}

Data produksi produksi gas silase tebon jagung masing-masing perlakuan tersaji dalam tabel 1 .
Tabel 1. Menunjukkan bahwa laju produksi gas pada awalnya cukup pelan pada jam ke 0 hingga jam ke 16. Pada interval waktu ini, mikroba rumen masih perlu adaptasi dengan lingkungan baru sehingga laju produksi gasnya masih pelan. Produksi gas pada di interval waktu 16 hingga 48 jam meningkat pesat karena pada masa ini, mikroba rumen telah memasuki fase eksponensial dalam fase hidupnya dan sudah beradaptasi dengan kondisi lingkungan baru mereka, pada saat yang sama substrat dilingkungannya masih banyak sehingga mikroba rumen dapat memproduksi gas dengan optimal. Data ini sesuai dengan penelitian Karabulut, Canbolat, Kalkan, Gurbuzol, Sucu, and Filya (2007) dimana data produksi gas meningkat hampir dua kali lipat saat interval waktu pengamatan 12 dan 24 jam.

Tabel 1. Rataan nilai produksi gas silase tebon jagung Inkubasi $0,2,4,8,12,16,24,36,48$, 72 dan 96 jam.

\begin{tabular}{cccccccccccc}
\hline \multicolumn{10}{c}{ Lama inkubasi (jam) } \\
\hline \multirow{2}{*}{ Perlakuan } & \multicolumn{10}{c}{ coduksi Gas (ml/500mgBK) } \\
\cline { 2 - 12 } ML0 & 0,0 & 2 & 4 & 8 & 12 & 16 & 24 & 36 & 48 & 72 & 96 \\
\hline ML10 & 0,0 & 4,8 & 7,3 & 13,8 & 23,5 & 33,8 & 46,5 & 63,7 & 77,2 & 92,5 & 97,7 \\
ML20 & 0,0 & 5,7 & 8,8 & 15,2 & 23,2 & 36,7 & 46,5 & 61,5 & 76,0 & 89,2 & 97,0 \\
BL0 & 0,0 & 4,7 & 6,5 & 11,3 & 18,2 & 23,9 & 41,0 & 64,5 & 80,8 & 95,0 & 103,8 \\
BL10 & 0,0 & 7,7 & 10,8 & 15,7 & 23,2 & 27,0 & 46,3 & 67,5 & 80,8 & 93,2 & 100,5 \\
BL20 & 0,0 & 6,2 & 8,8 & 15,0 & 23,5 & 28,2 & 44,7 & 60,7 & 71,8 & 83,8 & 89,7 \\
PL0 & 0,0 & 4,7 & 7,5 & 11,7 & 19,2 & 22,5 & 40,3 & 60,2 & 75,2 & 86,7 & 94,5 \\
PL10 & 0,0 & 4,7 & 10,0 & 18,0 & 27,7 & 36,7 & 55,3 & 73,2 & 88,2 & 101,5 & 110,7 \\
PL20 & 0,0 & 6,8 & 10,7 & 19,2 & 30,5 & 37,7 & 56,5 & 75,2 & 90,0 & 102,2 & 108,0 \\
GL0 & 0,0 & 5,3 & 7,2 & 13,7 & 21,2 & 25,9 & 41,7 & 53,8 & 69,5 & 84,0 & 92,8 \\
GL10 & 0,0 & 4,0 & 6,7 & 12,3 & 23,5 & 36,5 & 65,0 & 82,3 & 96,8 & 112,5 & 120,0 \\
GL20 & 0,0 & 4,7 & 7,5 & 14,3 & 36,0 & 63,0 & 85,0 & 102,0 & 114,7 & 127,7 & 135,0 \\
\hline
\end{tabular}

Keterangan: *Hasil Analisis Laboratorium Nutrisi dan Makanan Ternak Fakultas Peternakan Universitas Brawijaya (2020).

Kenaikan yang pesat ini diasumsikan karena mikroba rumen perlu beradaptasi dengan pakan yang baru sehingga perlu waktu untuk menghasilkan produksi gas yang efektif. Produksi gas mulai turun kecepatannya pada jam ke 48 hingga 96 jam karena substrat di lingkungan mereka mulai habis sehingga menyebabkan laju produksi gasnya mulai turun. Pada fase ini, mikroba rumen telah memasuki fase stasioner dalam fase hidupnya yakni fase ketika bakteri yang baru hidup sama banyaknya dengan bakteri yang mati, substrat yang mulai habis dan zat-zat hasil fermentasinya sudah mulai 
banyak. Fermentasi pakan dalam rumen selain menghasilkan Volatile Fatty Acid (VFA) juga mnghasilkan gas - gas seperti $\mathrm{CO}_{2}, \mathrm{CH}_{4}, \mathrm{NO}_{2}$, dan $\mathrm{NO}$ (Perry, et.al. 2003), $\mathrm{N}_{2}$ dan 3,5\% $\mathrm{O}_{2}$. (Fajri, dkk. 2018). Gas gas tersebut dihasilkan dari fermentasi bahan organik yang terkandung dalam pakan yang dikonsumsi oleh ternak. Tinggi rendahnya volume gas yang dihasilkan bergantung pada kandungan nutrisi dari pakan tersebut.

Semakin tinggi kadar karbohidrat yang terkandung pakan tersebut maka semakin tinggi pula gas yang dihasilkan fermentasi pakan tersebut dalam rumen. Selain itu, kandungan tanin dalam pakan akan menghambat kinerja enzim dan mikroba rumen sehingga akan menurunkan produksi gas total (Makkar, et. al.. 1995). Pola produksi gas silase tebon jagung jika diganbarkan dalam bentuk grafik akan berbentuk eksponensial, yakni garisnya akan naik seiring dengan bertambahnya lama waktu inkubasi. Grafik produksi gas total silase tebon jagung masing-masing perlakuan tersaji dalam gambar 1 .

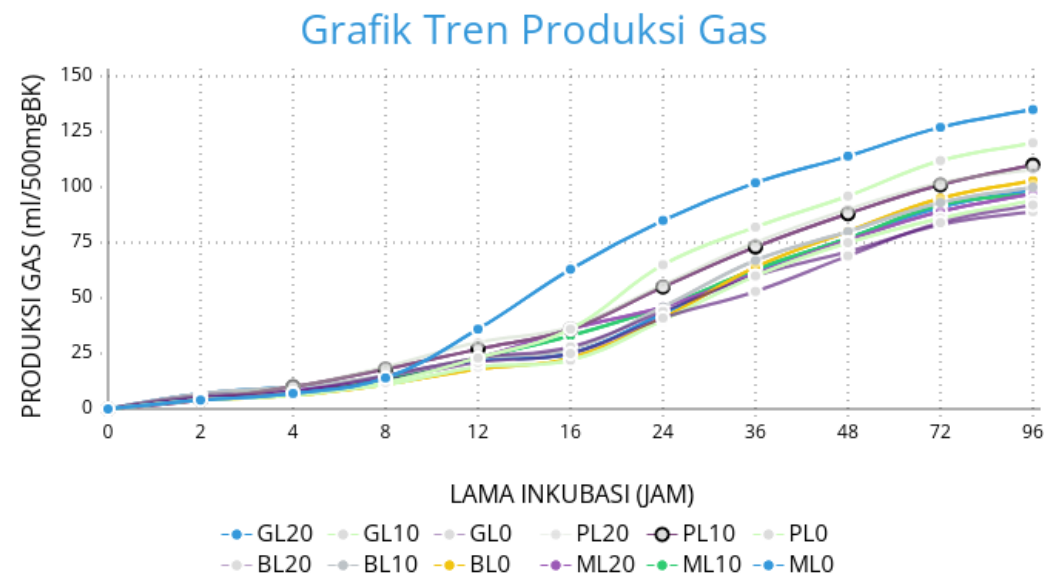

Gambar 1. Grafik tren produksi gas hingga 96 jam tebon Jagung

\section{Produksi Gas Total}

Hasil pengukuran produksi gas total silase tebon jagung masing-masing perlakuan tersaji dalam Tabel 2. Tabel 2 menunjukkan bahwa perlakuan penambahan aditif memberikan pengaruh yang tidak nyata $(\mathrm{P}>0,05)$ terhadap produksi gas silase tebon jagung dengan rataan 104,10 $\mathrm{ml} / 500 \mathrm{mgBK}$, namun tepung gaplek mempunyai kecenderungan produksi gas tertinggi dengan nilai $115,37 \mathrm{ml} / 500 \mathrm{mgBK}$. karena tepung gaplek mengandung bahan organik yang cukup sehingga mudah didegradasi menghasilkan produksi gas

Merujuk pada tabel 2, level aditif memberikan pengaruh yang sangat nyata $(\mathrm{P}<0,01)$ pada silase tebon jagung, karena dengan semakin meningkatnya level dari $\mathrm{L}_{0}$ hingga $\mathrm{L}_{20}$, ketersediaan bahan organik yang dapat didegradasi oleh mikroba akan semakin banyak sehingga akan meningkatkan nilai degradasi silase yang pada akhirnya juga akan meningkatkan nilai produksi gas.

Mengacu pada Tabel 2, produksi gas terbaik dihasilkan oleh perlakuan penambahan tepung gaplek 20\% (GL 20$)$ dengan nilai total produksi gas yang dihasilkan sejumlah $135 \mathrm{ml} / 500 \mathrm{mgBK}$. produksi gas yang dihasilkan dari perlakuan penambahan tepung gaplek $20 \%$ berbeda sangat nyata $(\mathrm{P}<0.01)$ dengan perlakuan lain. Tingginya gas yang dihasilkan oleh perlakuan penambahan tepung gaplek $20 \%$ menandakan bahwa silase dengan penambahan tepung gaplek $20 \%$ memiliki laju degradasi tertinggi dibanding perlakuan lainnya. Sehingga meningkatkan jumlah bahan organik yang didegradasi oleh mikroba dalam rumen dan juga energi yang disuplai dari pakan tersebut lebih tinggi dibandingkan penambahan bahan aditif 
lainnya. Produksi gas yang tinggi pada perlakuan penambahan tepung gaplek $20 \%$ disebabkan karena degradasi bahan kering silase dengan perlakuan penambahan tepung gaplek $20 \%$ tertinggi diantara perlakuan lain yakni $65,21 \pm 2,97 \%$. Tingginya nilai degradasi mengakibatkan lebih banyak bahan organik yang terdegradasi sehingga produksi gas lebih tinggi. Penelitian Makkar et. al. (1995) menunjukkan bahwa nilai laju degradasi yang tinggi juga menyebabkan nilai produksi gas total juga tinggi.

Tabel 2. Rataan produksi gas total silase tebon jagung.

\begin{tabular}{|c|c|c|c|c|c|}
\hline \multirow[b]{2}{*}{ Perlakuan } & \multicolumn{5}{|c|}{ Produksi Gas Total (ml/500mg BK) } \\
\hline & Molases (M) & Bekatul (B) & Pollard (P) & $\begin{array}{c}\text { Tepung Gaplek } \\
\text { (G) }\end{array}$ & Rataan \\
\hline $\mathrm{L}_{0}$ & $99,5 \pm 13,87^{\mathrm{cd}}$ & $103,83 \pm 10,32^{\mathrm{cd}}$ & $94,5 \pm 12,55^{\mathrm{d}}$ & $92,83 \pm 12,55^{\mathrm{d}}$ & $97,67 \pm 4,99^{b}$ \\
\hline $\mathrm{L}_{10}$ & $97,67 \pm 18,06^{\mathrm{cd}}$ & $100,5 \pm 8,26^{\mathrm{cd}}$ & $110,67 \pm 9,75^{\mathrm{bc}}$ & $120,0 \pm 11,46^{\mathrm{b}}$ & $107,21 \pm 10,19^{a}$ \\
\hline $\mathrm{L}_{20}$ & $97,0 \pm 13,75^{\mathrm{cd}}$ & $89,67 \pm 6,43^{\mathrm{d}}$ & $108,0 \pm 3,61^{\mathrm{bc}}$ & $135,0 \pm 4,09^{a}$ & $107,42 \pm 19,87^{\mathrm{a}}$ \\
\hline Rataan & $98,06 \pm 1,29$ & $98,00 \pm 7,41$ & $104,39 \pm 8,67$ & $115,37 \pm 21,37$ & $104,10 \pm 8,45$ \\
\hline Keterangan & $\begin{array}{r}\text { *Hasil Anal } \\
\text { Universitas } \\
* * \text { Rataan a } \\
\text { nyata }(\mathrm{P}>0,0 \\
\text { a-b } * * * \text { Superskri } \\
\text { yang sangat }\end{array}$ & $\begin{array}{l}\text { is Laboratorium } \\
\text { awijaya }(2020) \text {. } \\
\text { tif berbeda pada } \\
\text { yang berbeda pac } \\
\text { ata }(\mathrm{P}<0,01) \text {. }\end{array}$ & $\begin{array}{l}\text { utrisi dan } M \\
\text { ris yang sama } \\
\text { olom rataan le }\end{array}$ & $\begin{array}{l}\text { lan Ternak } \mathrm{F} \\
\text { nunjukkan pe }\end{array}$ & $\begin{array}{l}\text { tas Peternakan } \\
\text { laan yang tidak } \\
\text { edaan pengaruh }\end{array}$ \\
\hline
\end{tabular}

Fermentasi pakan dalam rumen selain menghasilkan Volatile Fatty Acid (VFA) juga mnghasilkan gas - gas seperti $\mathrm{CO}_{2}$, $\mathrm{CH}_{4}, \mathrm{NO}_{2}$, dan $\mathrm{NO}$ (Perry, et.al. 2003), $\mathrm{N}_{2}$ dan 3,5\% O2. (Fajri, dkk. 2018). Gas - gas tersebut dihasilkan dari fermentasi BO pakan yang dikonsumsi oleh ternak. Tinggi rendahnya volume gas yang dihasilkan bergantung pada laju degradasi dari pakan tersebut dalam rumen. Semakin laju degradasi pakan dalam rumen, tersebut maka semakin tinggi pula gas yang dihasilkan fermentasi pakan tersebut. Kandungan serat kasar dan zat antinutrisi dalam pakan akan sangat berpengaruh dalam degradasi pakan yang pada akhirnya akan mempengaruhi total produksi gas seperti kandungan tanin dalam pakan akan menghambat kinerja enzim dan mikroba rumen sehingga akan menurunkan produksi gas total (Makkar, et. al.. 1995).

Penambahan pollard pada pembuatan silase tebon jagung juga meningkatkan produksi gas sangat berbeda nyata $(\mathrm{P}<0.01)$ dibandingkan dengan penambahan bekatul dan molases meskipun tidak sebanyak penambahan tepung gaplek. Pollard memberikan pengaruh tertinggi saat pollard diberikan sebanyak $10 \%$. Perlakuan pollard $10 \%$ memiliki nilai produksi gas total sebanyak 110,67 $\pm 9,75 \mathrm{ml}$, lebih tinggi dibanding perlakuan pollard $20 \%$ memiliki nilai produksi gas total yakni sebanyak 108,0 \pm 3,61 ml dan L0 yakni sebesar 94,5 \pm $12,55 \mathrm{ml}$ dengan penambahan $0 \%$ ataupun $20 \%$ pollard yang membuktikan bahwa pollard juga meningkatkan nilai energi dan WSC silase. namun, Fajri, dkk. (2018) mengemukakan bahwa penambahan pollard dan bekatul meningkatkan lebih tinggi dibandingkan dengan penambahan pollard saja atau bekatul saja.

Berdasarkan Tabel 2, penambahan molases memiliki produksi gas terendah dengan perbedaan yang sangat nyata $(\mathrm{P}<0.01)$ dibanding dengan perlakuan lain dalam berbagai level, yang juga berarti silase dengan tambahan molases memiliki laju degradasi yang rendah. Hal ini diasumsikan karena molases memiliki kandungan BK yang rendah yakni sebesar $64,12 \%$, terendah dibandingkan dengan bekatul $(90,87 \%)$, pollard $(88,17 \%)$ dan tepung gaplek $(87,56 \%)$. Rendahnya kadar BK ini diasumsikan menjadi penyebab rendahnya produksi gas silase yang ditambah molases karena bakteri kekurangan bahan untuk difermentasi. Namun, penelitian Sariçiçek. Zehra and Kiliç (2009) menunjukkan bahwa 
penambahan molases memberikan produksi gas yang lebih tinggi dibandingkan dengan bahan aditif lain seperti pollard dan bekatul.

\section{Degradasi Bahan Kering (DBK) Secara} In Vitro

Hasil pengukuran degradasi bahan kering in vitro bahan kering silase tebon jagung masing-masing perlakuan disajikan dalam Tabel 3. Tabel 3 menunjukkan bahwa perlakuan Penambahan aditif memberikan pengaruh yang tidak nyata $(\mathrm{P}>0,05)$ terhadap DBK silase tebon jagung dengan rataan 56,26\%. Namun ada kecenderungan tepung gaplek mempunya nilai DBK tertinggi yakni 59,71\%. Hal ini karena tepung gaplek memiliki bahan organik dan BETN yang cukup dan serat kasar yang rendah.

DBK sangat bergantung pada kondisi fisik silase, silase dengan kadar serat kasar yang lebih tinggi akan lebih sulit dicerna karena mikroba rumen sulit mendegradasi pakan dengan ikatan lignin yang tinggi dalam serat kasar. Merujuk pada Tabel 3, level aditif memberikan pengaruh yang sangat nyata $(\mathrm{P}<0,01)$ terhadap DBK silase tebon jagung, karena dengan penambahan aditif akan meningkatkan kandungan bahan organik silase tebon jagung sehingga DBK silase tebon jagung meningkat. Kandungan bahan organik yang meningkat akan meningkatkan BETN yang merupakan subtrat yang mudah didegradasi mikroba rumen.

Tabel 3 menunjukkan bahwa DBK silase tertinggi dan secara statistik berbeda sanat nyata $(\mathrm{P}<0,01)$ terdapat pada perlakuan perlakuan penambahan tepung gaplek $20 \%$ yakni sebesar $65,21 \pm 2,97 \%$. Tingginya nilai DBK ini diasumsikan karena rendahnya kadar SK pada tepung gaplek yang menyebabkan kadar SK pada perlakuan juga relatif lebih rendah dan pada saat yang bersamaan, WSC pada tepung gaplek juga tinggi sehingga menyebabkan mikroba rumen mudah mencerna silase. penelitian Sha Du, Ming Xu dan Junhu Yao (2016) menunjukkan bahwa bahan yang mengandung SK lebih tinggi memiliki fraksi yang larut, potensial degradasi dan laju degradasi lebih rendah dibandingkan bahan yang mengandung SK lebih sedikit serta fraksi tidak larut dibandingkan dengan bahan yang mengandung SK lebih sedikit.

Tabel 3. Rataan nilai degradasi bahan kering silase tebon jagung.

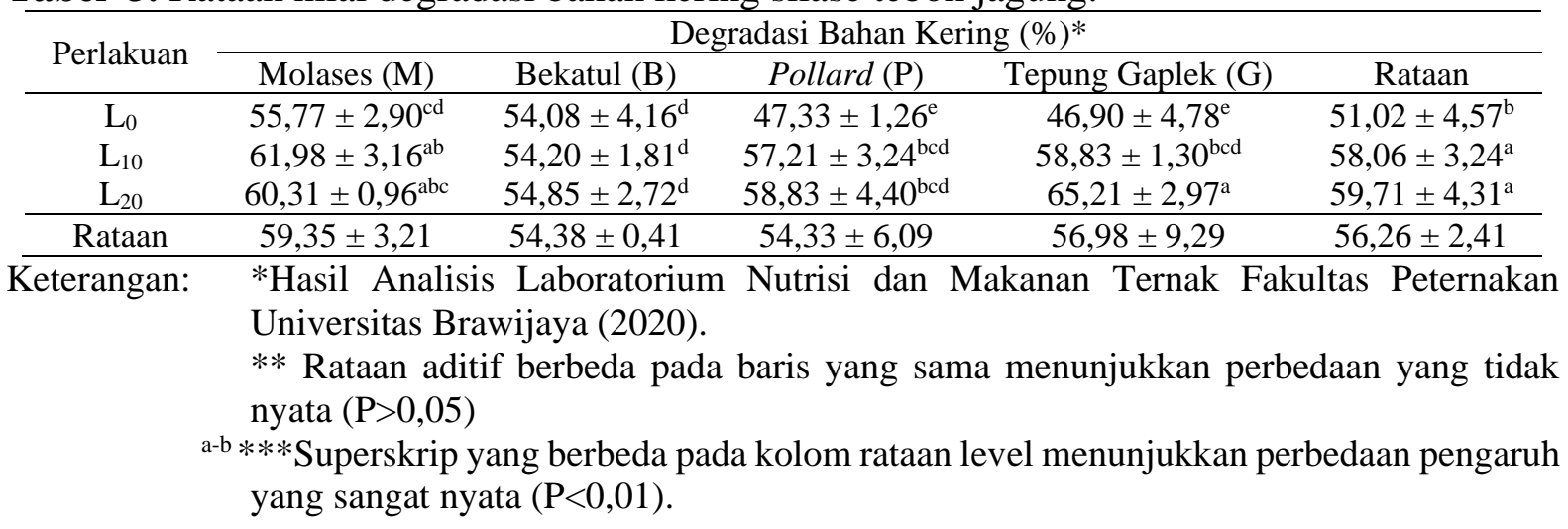

DBK pada perlakuan penambahan molases $10 \%$ yakni senilai $61,98 \pm 3,16 \%$ dan tidak berbeda secara statistik dengan perlakuan penambahan molases $20 \%$ yakni senilai $60,31 \pm 0,96 \%$. Nilai DBK yang tidak berbeda ini menunjukkan efektifitas keduanya realtif sama. Penambahan molases dalam pembuatan silase juga dapat meningkatkan nilai DBK silase karena molases yang banyak mengandung gula akan mempermudah BAL tumbuh dan memproduksi asam laktat yang akan menurunkan $\mathrm{pH}$ silase.

Penggunaan bekatul kurang disarankan karena memiliki nilai DBK terendah dibanding perlakuan lain dalam semua level yakni sebesar 54,20 $\pm 1,81 \%$ untuk penambahan $10 \%$ bekatul dan $54,85 \pm$ 
2,72 untuk penambahan $20 \%$ bekatul. Penambahan $0 \%$ bekatul menunjukkan DBK tertinggi dengan perbedaan yang sangat nyata $(\mathrm{P}<0,01) \quad$ dibanding penambahan $10 \%$ dan $20 \%$ bekatul. Bekatul yang memiliki kandungan serat kasar sebesar $16.93 \%$, lebih tinggi dibandng molases (0,25\%), Pollard (7,66\%) dan Tepung Gaplek (4,18\%). Kadar SK yang tinggi pada bekatul diduga menjadi penyebab nilai dergadasi pada perlakuan ini terendah. Kadar SK yang tinggi dalam bekatul menyebabkan kadar SK dalam silase dengan penambahan bekatul relatif lebih tinggi dibandingkan dengan penambahan bahan lain sehingga akan menurukan DBK

Berdasarkan pada Tabel 3, penambahan bahan aditif sebanayk $10 \%$ dan $20 \%$ dari berat segar tebon jagung akan tetap meningkatkan DBK silase tebon jagung dibanding dengan perlakuan kontrol (L0) yang mana L0 adalah silase tebon tanpa penambahan bahan aditif kecuali pada perlakuan penambahan bekatul. Kenaikan nilai DBK silase ini membuktikan bahwa penambahan aditif akan meningkatkan kadar WSC silase sehingga BAL akan semakin mudah menurunkan $\mathrm{pH}$ silase.

\section{Degradasi Bahan Organik (DBO) Secara In Vitro}

Hasil pengukuran degradasi bahan organik in vitro bahan organik silase tebon jagung masing-masing perlakuan tersaji dalam Tabel 4. Tabel 4. menunjukkan bahwa perlakuan Penambahan aditif memberikan pengaruh yang tidak nyata $(\mathrm{P}>0,05)$ terhadap DBO silase tebon jagung dengan rataan 58,24\%. Namun ada kecenderungan tepung gaplek mempunya nilai DBO tertinggi yakni $68,11 \%$. Hal ini karena tepung gaplek memiliki bahan organik yang tinggi namun serat kasarnya rendah. Tingginya bahan organik silase dan rendahnya serat kasar akan menyebabkan mikroba rumen lebih mudah mendegradasi pakan karena serat kasar merupakan komponen yang sulit dicerna mikroba rumen.

Tabel 4. Rataan nilai degradasi bahan organik silase tebon jagung.

\begin{tabular}{cccccc}
\hline \multirow{2}{*}{ Perlakuan } & \multicolumn{5}{c}{ Degradasi Bahan Organik $(\%)^{*}$} \\
\cline { 2 - 5 } & Molases $(\mathrm{M})$ & Bekatul $(\mathrm{B})$ & Pollard $(\mathrm{P})$ & Tepung Gaplek $(\mathrm{G})$ & Rataan \\
\hline $\mathrm{L}_{0}$ & $56,99 \pm 4,37^{\mathrm{c}}$ & $58,62 \pm 0,47^{\mathrm{bc}}$ & $46,88 \pm 3,53^{\mathrm{e}}$ & $45,49 \pm 5,60^{\mathrm{e}}$ & $52,00 \pm 6,77^{\mathrm{b}}$ \\
$\mathrm{L}_{10}$ & $60,69 \pm 3,14^{\mathrm{b}}$ & $56,22 \pm 2,38^{\mathrm{cd}}$ & $62.03 \pm 3,20^{\mathrm{b}}$ & $61.10 \pm 3,08^{\mathrm{b}}$ & $60,01 \pm 2,59^{\mathrm{a}}$ \\
$\mathrm{L}_{20}$ & $60,59 \pm 2,04^{\mathrm{b}}$ & $54,82 \pm 0,55^{\mathrm{d}}$ & $56,57 \pm 2,87^{\mathrm{cd}}$ & $68,11 \pm 2,18^{\mathrm{a}}$ & $60,02 \pm 5,91^{\mathrm{a}}$ \\
\hline Rataan & $59,42 \pm 2,11$ & $56,55 \pm 1,91$ & $55,16 \pm 7,67$ & $58,24 \pm 11,58$ & $57,34 \pm 1,87$ \\
\hline
\end{tabular}

Keterangan: *Hasil Analisis Laboratorium Nutrisi dan Makanan Ternak Fakultas Peternakan Universitas Brawijaya (2020).

** Rataan aditif berbeda pada baris yang sama menunjukkan perbedaan yang tidak nyata $(\mathrm{P}>0,05)$

a-b ***Superskrip yang berbeda pada kolom rataan level menunjukkan perbedaan pengaruh yang sangat nyata $(\mathrm{P}<0,01)$.

Merujuk pada Tabel 4, level aditif memberikan pengaruh yang sangat nyata $(\mathrm{P}<0,01)$ terhadap DBO silase tebon jagung, karena dengan penambahan aditif kandungan bahan organik akan semakin meningkat yang menyebabkan naiknya aktivitas mikroba rumen mendegradasi pakan sehingga DBO akan semakin meningkat.

Tabel 4 menunjukkan DBO tertinggi dan secara statistik berbeda terdapat pada perlakuan perlakuan penambahan tepung gaplek $20 \%$ yakni $68,11 \pm 2,18 \%$. Nilai DBO yang tinggi ini diasumsikan karena SK dalam silase dengan penambahan tepung gaplek 20\% relatif rendah. Lignin dalam SK adalah komponen serat yang menghambat DBO silase dalam rumen sehingga kadar SK yang tinggi dalam silase meningkatkan kadar lignin dalam silase yang juga akan menurunkan nilai DBO. Reffenato, Fievisohn, Cotanch, Grant, Chase, and Van Amburgh (2017) mengemukakan bahwa lignin dan ikatan lignin dengan ADF dan 
NDF dalam bahan pakan menurukan DBO bahan pakan oleh mikroba rumen. Penggunaan pollard sebanyak $10 \%$ dari berat segar tebon jagung memiliki DBO tertinggi kedua setelah tepung gaplek yakni sebesar $62.03 \pm 3,20 \%$, tidak berbeda secara statistik dengan penambahan $10 \%$ tepung gaplek yang memiliki DBO sebasar $61.10 \pm$ 3,08 .

Pollard memberikan pengaruh tertinggi saat pollard diberikan sebanyak $10 \%$. Perlakuan pollard $10 \%$ memiliki nilai DBO sebanyak $62.03 \pm 3,20 \%$. Tertinggi dan berbeda sangat nyata $(\mathrm{P}<0,01)$ dibanding perlakuan pollard $20 \%$ memiliki nilai DBO yakni sebanyak $56,57 \pm 2,87 \%$ dan PL0 yakni sebesar 46,88 $\pm 3,53 \%$. Pada perlakuan penambahan pollard $20 \%$ dari berat segar tebon jagung menunjukkan adanya penurunan dibanding dengan penambahan pollard $10 \%$ dari berat segar tebon jagung yakni sebedar 56,57 $\pm 2,87 \%$. Hal ini menunjukkan bahwa penggunaan efektif pollard dalam pembuaatan silase berkisar di angka $10 \%$ dari berat segar tebon jagung. Namun, penelitian Fajri, dkk (2018) menunjukkan bahwa DBO tertinggi didapat pada perlakuan silase dengan penambahan pollard $10 \%$ dan bekatul $10 \%$. Perlakuan tersebut lebh tinggi dibandingkan dengan perlakuan penambahan pollard $10 \%$ saja.

Nilai DBO terendah terdapat pada perlakuan pnambahan bekatul sebanyak $20 \%$ dari berat segar tebon jagung yakni $54,82 \pm 0,55 \%$. Hal ini karena kandungan serat kasar bekatul sebesar $16.93 \%$, lebih tinggi dibandng molases $(0,25 \%)$, Pollard $(7,66 \%)$ dan Tepung Gaplek $(4,18 \%)$. Kadar SK dalam bekatul yang lebih tinggi juga mengakibatkan kadar lignin dalam silase dengan penambahan bekatul lebih tinggi dibandingkan perlakuan lain karena lignin merupakan salah satu komponen serat dan merupakan bahan yang sulit didegradasi mikroba rumen.

Berdasarkan pada Tabel 4, penambahan bahan aditif sebanyak $10 \%$ dan $20 \%$ dari berat segar tebon jagung akan tetap meningkatkan DBO silase tebon jagung dibanding dengan perlakuan kontrol (L0) kecuali pada perlakuan penambahan bekatul yang mana L0 adalah silase tebon tanpa penambahan bahan aditif. Data ini menunjukkan bahwa pemberian aditif akan meningkatkan WSC silase. Namun, khusus pada pelakuan bekatul, penambahan bahan aditif berupa bekatul selain dapat menaikkan WSC silase, juga dapat menaikkan kadar SK silase sehingga silase lebih sulit dicerna oleh mikroba rumen.

\section{Perhitungan Harga Silase}

Penambahan aditif dalam pembuatan silase akan menambah biaya produksi silase, yang akan berdampak pada harga produk silase. harga produk silase yang terlalu tinggi akan menjadi pertimbangan dalam membuat silase sebagai pakan ternak karena $60-70 \%$ biaya dalam usaha peternakan adalah biaya pakan.

Penelitian Irawan, Nugroho dan Utami (2013) menunjukkan bahwa biaya pakan menyumbang $87 \%$ dari biaya tidak tetap (Variable Cost). Hal ini juga didukung oleh penelitian Happyna (2017) yang menunjukkan bahwa biaya pakan memiliki pengaruh yang nyata terhadap keuntungan petenak, oleh sebab itu meminimalisir biaya pakan sangat diperlukan untuk menambah keuntungan peternak. Harga permbuatan silase masing masing perlakuan tersaji dalam Tabel 5.

Berdasarkan perhitungan harga bahan baku dalam pembuatan silase maka diantara harga silase yang menggunakan aditif dengan harga termurah adalah silase dengan penambahan aditif bekatul $10 \% \quad\left(\mathrm{BL}_{10}\right)$ namun, dengan mempertimbangan nilai produksi gas, DBK dan DBO terbaik, makan perlakuan terbaik pada silase dengan penambahan tepung gaplek $\left(\mathrm{GL}_{20}\right)$ dengan harga Rp. 3.000,00 per $\mathrm{kg}$ silase. Tabel 5 menyajian data bahwa semua aditif masih memiliki harga yang relatif murah untuk setiap perlakuan. Harga yang murah akan membuat silase dalam penelitian ini selain memiliki kelayakan teknis dari sisi nutriennya, juga memiliki kelayakan finansial dari sisi harga pembuatannya. 
Tabel 5. Perhitungan harga silase tebon jagung masing-masing perlakuan

\begin{tabular}{cccc}
\hline Perlakuan & $\begin{array}{c}\text { Harga Tebon Jagung (Per kg } \\
\text { silase) }\end{array}$ & $\begin{array}{c}\text { Harga aditif (Per kg } \\
\text { silase) }\end{array}$ & $\begin{array}{c}\text { Harga silase (per kg } \\
\text { silase) }\end{array}$ \\
\hline ML0 & Rp. $1.000,00$ & - & Rp. $1.000,00$ \\
ML10 & Rp. $1.000,00$ & Rp. $1.500,00$ & Rp. $2.500,00$ \\
ML20 & Rp. $1.000,00$ & Rp. $3.000,00$ & Rp. $4.000,00$ \\
BL0 & Rp. $1.000,00$ & - & Rp. $1.000,00$ \\
BL10 & Rp. $1.000,00$ & Rp. 400,00 & Rp. $1.400,00$ \\
BL20 & Rp. $1.000,00$ & Rp. 800,00 & Rp. $1.800,00$ \\
PL0 & Rp. $1.000,00$ & - & Rp. $1.000,00$ \\
PL10 & Rp. $1.000,00$ & Rp. 800,00 & Rp. $1.800,00$ \\
PL20 & Rp. $1.000,00$ & Rp. $1.600,00$ & Rp. $2.600,00$ \\
GL 0 & Rp. $1.000,00$ & - & Rp. $1.000,00$ \\
GL10 & Rp. $1.000,00$ & Rp. $1.000,00$ & Rp. $2.000,00$ \\
GL20 & Rp. $1.000,00$ & Rp. $2.000,00$ & Rp. $3.000,00$ \\
\hline
\end{tabular}

Keterangan: Harga silase dihitung berdasarkan persentase penggunaan bahan aditif dari berat tebon dan harga beli aditif saat pembuatan silase.

\section{KESIMPULAN}

Penambahan bahan aditif molases, bekatul, pollard, dan Tepung Gaplek dapat meningkatkan nilah produksi gas, DBK dan DBO pakan secara in vitro silase tebon jagung dengan perlakuan terbaik adalah penambahan Tepung Gaplek sebanyak 20\% dengan produksi gas total sebanyak $135,1 \pm$ 4,09 $\mathrm{ml}, \mathrm{DBK}$ sebesar 65,21 $\pm 2,97 \%$ dan DBO $68,11 \pm 2,18 \%$. Berdasarkan hasil penelitian ini, disarankan dalam pembuatan silase menggunakan bahan aditif tepung gaplek sebanyak $20 \%$.

\section{DAFTAR PUSTAKA}

Bunyamin, Z., Efendi, R., Andayani, N. N., Penelitian, B., \& Serealia, T. (2013). Pemanfaatan Limbah Jagung untuk Industri Pakan Ternak. Seminar Nasional Inovasi Teknologi Pertanian, 1(1), 153-166.

Caetano, H., Oliveira, M. D. S., Freitas Júnior, J. E., Rêgo, A. C., Carvalho, M. V., \& Rennó, F. P. (2011). Nutritional characteristics and in vitro digestibility of silages from different corn cultivars harvested at two cutting heights. Revista Brasileira de
Zootecnia, 40(4), 708-714. https:// doi.org/10.1590/S1516-3598201100 0400002

Despal., Hidayah., \& Lubis, A. D. (2017). Kualitas silase jagung di dataran rendah tropis pada berbagai umur panen untuk sapi perah tropical. Buletin Makanan Ternak, 104(3), 10-20.

Du, S., Xu, M., \& Yao, J. (2016). Relationship between fibre degradation kinetics and chemical composition of forages and byproducts in ruminants. Journal of Applied Animal Research, 44(1), 189193. https://doi.org/10.1080/0971211 9.2015.1031767

Forejtová, J., Lád, F., Třináctý, J., Richter, M., Gruber, L., Doležal, P., Homolka, P., \& Pavelek, L. (2011). Comparison of organic matter digestibility determined by in vivo and in vitro methods. Czech Journal of Animal Science, 50(No. 2), 47-53. https:// doi.org/10.17221/3994-CJAS

Happyana, D. (2017). Analisis tingkat keuntungan usaha penggemukan sapi potong rakyat di kabupaten wonogiri. Jurnal Ilmiah Peternakan Terpadu, 5(2), 33-39. https://doi.org/10.23960/ jipt.v5i2.p33-39 
Hartutik, H., Fajri, A. I., \& Irsyammawati, A. (2018). Pengaruh penambahan pollard dan bekatul dalam pembuatan silase rumput odot (Pennisetum purpureum, Cv.Mott) terhadap kecernaan dan produksi gas secara in vitro. Jurnal Nutrisi Ternak Tropis, 1(1), 9-17. https://doi.org/10.21776/ ub.jnt.2018.001.01.2

Irawan, T., Nugroho, B., \& Utami, H. (2013). Analisis ekonomi usaha peternakan sapi potong di Tulungagung (studi kasus pada dua usaha penggemukan sapi potong skala menengah). Research Article.

Karabulut, A., Canbolat, O., Kalkan, H., Gurbuzol, F., Sucu, E., \& Filya, I. (2007). Comparison of in vitro gas production, metabolizable energy, organic matter digestibility and microbial protein production of some legume hays. Asian-Australasian Journal of Animal Sciences, 20(4), 517-522. https://doi.org/10.5713/ajas. 2007.517

Khota, W., Pholsen, S., Higgs, D., \& Cai, Y. (2018). Comparative analysis of silage fermentation and in vitro digestibility of tropical grass prepared with Acremonium and Tricoderma species producing cellulases. AsianAustralasian Journal of Animal Sciences, 31(12), 1913-1922. https://doi.org/10.5713/ajas.18.0083

Makkar, H. P., Blummel, M., \& Becker, K. (1995). Formal complexes between polyvinyl pyrrolidones or polyethylene glycols and tannins, and their implication in gas production and true digestibility in in vitro techniques. British Journal of Nutrition, 897-913.

Perry, T., Wayne, A., Cullison, \& Lowrey, R. (2003). Feeds and Feeding (6th ed.). Pearson Education. Inc.

Raffrenato, E., Fievisohn, R., Cotanch, K. W., Grant, R. J., Chase, L. E., \& Van Amburgh, M. E. (2017). Effect of lignin linkages with other plant cell wall components on in vitro and in vivo neutral detergent fiber digestibility and rate of digestion of grass forages. Journal of Dairy Science, 100(10), 8119-8131. https:// doi.org/10.3168/jds.2016-12364

Sariçiçek, B., Zehra, \& Kiliç, Ü. (2009). The effects of different additives on silage gas production, fermantation kinetics and silage quality. Ozean Journal of Applied Sciences., 2(1), 11-18.

Sjofjan, O., \& Adli, D. N. (2021). The effect of replacing fish meal with fermented sago larvae (FSL) on broiler performance. Livestock Research for Rural Development, 33(2).

Sjofjan, O., Nur Adli, D., Djunaidi, I., \& Kuncoro, K. (2020). Utilization of biogas liquid waste for starter in the fermentation of rice husk as a potential feed for poultry. Animal Production, 22(1), 24-30. https://doi.org/10.20 884/1.jap.2020.22.1.38 